CHINESE POETRY 



\section{CHINESE POETRY}

\section{AN ANTHOLOGY OF MAJOR MODES AND GENRES}

Wai-lim Yip, Editor and Translator

Duke University Press Durham and London 1997 
4th printing, 2003

C 1997 Duke University Press

All rights reserved

Printed in the United States of America on acid-free paper $\infty$ Designed by Mary Mendell

Typeset in Minion at Duke University Press

Library of Congress Cataloging-in-Publication Data appear on the last printed page of this book. 
FOR TZU-MEI

JUNE AND JONAS 
